\title{
Beliefs about Climate Change and Their Relationship with Environmental Beliefs and Sustainable Behavior: A View from Rural Communities
}

\author{
Willian Sierra-Barón ${ }^{1, *}\left(\mathbb{D}\right.$, Oscar Navarro ${ }^{2}{ }^{\oplus}$, Diana Katherine Amézquita Naranjo ${ }^{1}($, \\ Eylyn Daniela Teres Sierra ${ }^{1}$ (I) and Carol Marcela Narváez González ${ }^{1}$ (I) \\ 1 Faculty of Social and Human Sciences, Surcolombiana University, Neiva 410001, Colombia; \\ diianakatherine@hotmail.com (D.K.A.N.); eylyndts27@hotmail.com (E.D.T.S.); \\ camanago.15@hotmail.com (C.M.N.G.) \\ 2 Laboratoire de Psychologie des Pays de la Loire, University of Nantes, 44000 Nantes, France; \\ oscar.navarro@univ-nantes.fr \\ * Correspondence: willian.sierra@usco.edu.co
}

check for updates

Citation: Sierra-Barón, W.; Navarro, O.; Amézquita Naranjo, D.K.; Teres Sierra, E.D.; Narváez González, C.M. Beliefs about Climate Change and Their Relationship with

Environmental Beliefs and Sustainable Behavior: A View from Rural Communities. Sustainability 2021, 13, 5326. https://doi.org/ $10.3390 /$ su13095326

Academic Editor: Ernesto Suarez

Received: 16 March 2021

Accepted: 21 April 2021

Published: 10 May 2021

Publisher's Note: MDPI stays neutral with regard to jurisdictional claims in published maps and institutional affiliations.

Copyright: (c) 2021 by the authors. Licensee MDPI, Basel, Switzerland. This article is an open access article distributed under the terms and conditions of the Creative Commons Attribution (CC BY) license (https:/ / creativecommons.org/licenses/by/ $4.0 /)$.

\begin{abstract}
The study of beliefs and environmental behavior is of special interest, given the implications of climate change as a social phenomenon and the disagreements about what is socially believed about this phenomenon. This research was aimed at determining the associations between environmental beliefs and sustainable behavior in a group of inhabitants of southern Colombia. The methodology was exploratory and cross-sectional, with descriptive and correlational analyses. The sample was made up of 368 people from two regions in southern Colombia $(57.5 \%$ female and $42.5 \%$ male); their ages ranged between 18 and 69 years $(X=19.36$; $S D=8.59)$. Information was collected with questionnaires that measured climate change risk perception, environmental beliefs, and sustainable behavior. The results show higher scores for equitable behavior and environmental beliefs. Environmental beliefs-egobiocentrism—and risk perception of climate change predict both sustainable and pro-ecological behavior, as well as altruistic, frugal, and equitable behavior. It is concluded that the presence of environmental beliefs, along with information regarding a sense of environmental deterioration, climate change and the consequences for the future, can predict the implementation of actions for sustainable development.
\end{abstract}

Keywords: environmental beliefs; sustainable behavior; climate change; Colombia; sustainable development; altruism; frugality; equity

\section{Introduction}

Humanity is facing a social and environmental crisis due to the privilege of the ideologies of progress and unlimited economic growth, which has had adverse impacts on the biosphere that can become irreversible [1-3]. The way individuals, groups, organizations, and society in general perceive nature, the external factors that impact it, and how they are related, are affected by many factors. Thus, talking about relations between human beings and the environment implies questioning which human beings and what particular environment are to be analyzed [4].

There is more and more literature describing the profound and potentially devastating effects that climate change has on the planet, as well as the need to address this problem and its respective mitigation processes $[5,6]$, the starting point of which is the premise of scientific understanding of this phenomenon. The causes of climate change are mainly due to human activity (individual and collective), and it endangers human and natural systems [7]. Among its aggravating factors, climate change not only represents a physical phenomenon, but also a social phenomenon that involves temporal, spatial, and political variability $[5,8]$. 
In this respect, climate change as a social phenomenon is influenced by people's beliefs; these beliefs eventually guide their behaviors [8]. Despite this, and the increasing scientific consensus over human influences on climate change, it is worrying that in some places in the world (especially in developing areas of Western societies), people do not believe in the human causes of this phenomenon [9], which explains the variability produced by its social implications. Regardless of the causal attribution of climate change, there is abundant scientific evidence about how climate change affects human health and, in turn, a growing tendency to admit the explicit consequences for mental health and well-being, the vulnerability of which may be greater in rural communities [10]. Recent geographic research brings to light the differences between rural and urban populations that influence the way people behave and care about the environment, and which may be due to current circumstances or child socialization in these places [11]. As part of this process, there is evidence that accounts for the efforts of urban and rural communities and organizations to contribute to the conservation of their habitat, as a consequence of different issues. Clerici et al. [12] show how deforestation is affecting Colombian protected areas during post-conflict periods and how the leading role of communities, their leadership, and organization, are starting points to contribute to solving this problem. Zelazna et al. [13] and Esteban-Salvador et al. [14] describe the most frequent environmental activities carried out by companies operating in the Lublin region (Poland) and rural areas of Spain, respectively, aimed at protecting the environment. In addition, Barclay and Barker [15] showed how environmentalism contributes to the recognition of how people see the value in others, and therefore, contributes to the intention of carrying out collective and collaborative actions.

Thus, beliefs about climate change are based on relatively stable cognitive characteristics, such as values, ideologies, and world views, and it is therefore not usually easy to change them through superficial educational processes, such as information campaigns and messages [16]. Another significant factor is the perception of climate change, which is a subjective evaluation coming both from experience (daily experiences from internal and external sources) and personality aspects, and promotes individual interpretation of behavior and climatic contexts, which is essential for the development of suitable approaches to this phenomenon [8,17-21].

These beliefs about the causes of climate change or the perception of the risk involved are related to environmental beliefs, that is, the way people conceive the relationship between humans and their environment or the planet. Human-natural environment interaction has essentially been studied through three types of beliefs: anthropocentrism (which conceives of humans as exerting dominance over nature independently from it and with the ability to transform it at their discretion), egobiocentrism (which values the effects of nature on human beings positively), and biosphereism (which conceives of nature its intrinsic value and goodness, facilitating the connection between living beings). These three types of beliefs account for the consequences for the environment [22-28]. The strong presence of anthropocentrism contributes to dysfunctional behavior [29], which in recent decades, has contributed negatively to climate variations and changes in the different natural ecosystems of the world [30-32], such as the worldwide increase in temperature, the decrease in the area and thickness of the ice layers of the Arctic seas, the increase in sea level, air pollution, the displacement of flora and fauna, high latitudes and world economic losses related to meteorological phenomena [33-35]. Studies in different countries show how beliefs have strong implications for environmental behavior in workers [36], tourists [37], and even families [38].

Different scientific disciplines highlight the importance of considering a sustainable development framework, which would allow a balance to be maintained between satisfying human needs and preserving and restoring the environment [39]. This, in turn, implies that people's behaviors not only have a pro-environmental scope, understood as actions aimed at protecting the environment as well as the human social environment (involving political and economic elements) $[40,41]$, but also that said behaviors must reach a sustainable 
dimension, that is, one that includes the protection of the natural and cultural resources of the entire planet for global benefit $[1,42]$.

Authors such as Rascón and Corral [39] state the existence of a significant relationship between the performance of sustainable actions and the positive influence at an intrinsic level taking place when acting prosocially and in favor of the environment. In addition, García and collaborators [1] highlight the close relationship between connectivity with nature and sustainable behavior. This leads to the notion that people's actions in favor of the environment could be influenced by their level of connection to nature and be latent in them.

In addition to this, Barrera-Hernández and collaborators [43] state that people's positive perceptions of the environment influence the development of frugal, pro-ecological, altruistic, and equitable actions on their part, which are the conditions for producing sustainable behavior [41]. In this respect, sustainable development aims for current and future generations to have access to environmental resources and to satisfy their needs [39]. Thus, sustainable behavior refers to the group of actions aiming to protect the planet's sociophysical resources. This includes frugal, pro-ecological, altruistic, and equitable actions $[41,44]$. In this sense, it is necessary to describe each of the actions of sustainable behavior, which are mentioned here.

Frugality is understood as a measured consumption behavior, which implies the efficient use of natural resources with the avoidance of waste and clever use of goods [42,45-48]. In this respect, some authors, such as Bhatti [49] and Pires and collaborators [50], highlight the need to promote the use of resources in a responsible and ingenious way, as well as their ecological value for the future in the short and long term.

Moreover, pro-ecological behavior is understood as the decisive and effective actions carried out by people at an individual or social level, aiming at favoring the protection of the natural environment and the conservation of resources [41,44]. This behavior is associated with positive psychological states, as people with high levels of happiness tend to show a higher frequency of pro-ecological practices [51].

In this context, altruism is understood as the tendency to maximize other people's interests and benefits over self-interest, an attribute related to desirable consequences and personal responsibility from the activation model of the norm [52-54]. In altruism, the interest is not economic since it mainly seeks the satisfaction of doing something that leads to positive consequences for other people [55]. That is why altruistic people act disinterestedly and in favor of others without expecting anything in return [51,56,57].

Equity is a principle-based behavior that leads to the fair allocation of resources among individuals, without differentiated treatment towards people, and avoiding biases among individuals. It also implies a balance between human well-being and the integral relationship of ecosystems, making it possible to have access to resources $[41,42,58]$. While equity is a condition that includes aspects at the social level, health, education, and quality of life [51], equitable practices lead to states of happiness and a greater sensitivity connection with nature [59].

Research in environmental psychology uses rigorous methods to inquire about perceptions, social and individual cognitions, and psychological well-being related to conceptions of climate change and its effects $[60,61]$, with greater developments in urban contexts. However, very few inhabitants of rural regions are involved, and much less so the indigenous communities that represent a high percentage of the population of Latin American countries. There is only sparse literature in social and environmental psychology regarding the possible associations between sustainable behavior and its defining characteristics (pro-ecological, altruistic, frugal, and equitable behavior), environmental beliefs, or beliefs regarding the causes of climate change and risk perception of this phenomenon, which is the reason why this study was conceived: it involves rural populations in its sample.

Thus, whether the implications of climate change are physical or a social phenomenon, they impact people's beliefs, which in turn influence friendly behavior towards the environment, which in turn particularizes perceptions of climate change in individuals and groups. 
It is, therefore, necessary to carry out studies leading to the development of behavioral strategies that prevent environmental deterioration and mitigate the effects of climate change. These effects are seen more severely in developing countries, which is why it is essential to investigate beliefs about climate change and its possible impact on behavior. From the above-mentioned, the following hypotheses are put forward. H1: Beliefs about climate change coincide with environmental beliefs, in the sense that anthropocentric beliefs correlate positively with the belief in the natural cause of climate change, that is, human action is not responsible; H2: Beliefs about climate change and environmental beliefs predict sustainable behavior, in the sense of the anthropic cause of climate change, that is, that human activity is responsible for it, and egobiocentric beliefs predict sustainable behavior in all its dimensions.

This research was aimed at determining the associations between environmental beliefs and sustainable behavior in a group of inhabitants of southern Colombia, mostly from rural areas, and to prove a causal relation between environmental and climate change beliefs and sustainable behavior.

\section{Materials and Method}

This research is exploratory and cross-sectional, with descriptive and correlational analyses [62].

\subsection{Participants}

The sample was made up of 388 people located in two regions in southern Colombia. They participated in the research study voluntarily and were chosen using the convenience criterion. The convenience criterion was chosen in coherence with the methodological commitment that implied advancing the information collection process in a single moment in time (cross-sectional), in areas that are geographically difficult to access, and with inhabitants who work and have other activities. The research team, upon reaching people's homes, extended an invitation to participate in the study, receiving a response only from those who had the availability and time to fill out the questionnaire., The participants were $57.5 \%$ female and $42.5 \%$ male, with an age range of between 18 and 69 years $(X=19.36$; $S D=8.59)$. A total of $54.63 \%$ of them belong to the rural sector $(n=212), 28.35 \%$ to the rural indigenous sector of the Nasa community $(n=110)$, and $17.01 \%$ to the urban sector $(\mathrm{n}=66)$. Rural, indigenous, and urban inhabitants were contacted and surveyed directly in their homes. This distinction made it possible to classify the participants according to the place to which they belonged at the time of the research, which logistically implied for the research team to travel to these places. In turn, it was considered relevant to determine its effect on the study variables. For this reason, it is of special interest to broaden the understanding of beliefs towards climate change and its relationship with environmental beliefs and sustainable behavior in these population groups, due to the implications that their particularities have, especially at the socioeconomic level, as well as the dependence on natural resources for sustainability and living in areas of high risk of vulnerability to the effects of climate change. In the case of indigenous communities, it is relevant to consider the possible effects of their traditional ways of life as a means to explore future processes of adaptation and mitigation to climate change $[63,64]$ based on their environmental beliefs.

A total of $95.4 \%$ of the sample belonged to socioeconomic strata 1 and 2, which corresponds to users with low income levels, and are therefore represented as beneficiaries of subsidies in home public services. Of the participants, $77.3 \%$ have a primary and high school level of education, while $22.7 \%$ of them have received higher education. The environmental, social, and economic contexts that have characterized the recent history of the communities where the participants live are diverse. According to official figures from the latest population census, the Department of Huila has 1,009,548 inhabitants, of which $40 \%$ correspond to the rural population; $50.1 \%$ of the total population are women. The subjective poverty reported in the households surveyed stands at $34.8 \%$, and the unemployment rate is $9.2 \%$ (very close to the national average of $9.7 \%$ ). The most representative 
contributions to the department's Gross Domestic Product are from the sectors of public administration and defense, agriculture, livestock, and fish. The Department of Huila has a great variety of ecosystems that offer significant environmental services, from the great richness in biodiversity and life zones that go from the very dry tropical conditions in the Tatacoa Ecoregion to the Andean and High Andean Forests of the central and eastern mountain ranges. The indigenous population registered in the department numbers 10,335 inhabitants. The most representative environmental problems in this region are (i) the loss and fragmentation of strategic ecosystems and biological diversity, (ii) the decrease in the quality and quantity of surface water resources, (iii) the development of productive practices in an unsustainable and incompatible way for the environment, (iv) the increase in the occurrence of natural phenomena that threaten and put the population at risk, (v) urban effects related to noise, inadequate land use, pollution, and settlement in risk areas and, (vi) the lack of environmental authority and high incidence of infractions to environmental regulations [65]. The Department of Caquetá has 502,410 inhabitants, of which $39.25 \%$ belong to the rural sector; $50.4 \%$ of the total are women. In 2018 , approximately 170,753 people were declared victims of armed conflict. The multidimensional poverty index is $33.6 \%$. This department ranks as the third-highest nationally regarding greenhouse gas emissions. Deforestation is the main factor responsible for emissions, due to the expansion of the agricultural frontier over forest areas. Other environmental problems of greater relevance are associated with problems in the environmental management of the territory and climate change, the integral management of water resources, the inadequate management of biological diversity and ecosystem services, low capacity for environmental management, and the absence of processes strengthening environmental management in ethnic groups. In the area, 5026 people belong to indigenous communities [66]. This region of Colombia has an enormous environmental heritage at a national level, which is in line with social problems and economic and employability inequality. The consequences of armed conflict, the expansion of the agricultural frontier, the extraction of oil and other materials, as well as the absence of adequate waste management processes, and the already known effects of climate change allow some particularities of this Colombian region to be contextualized.

The description of the participants by group shows that more of them are female in the rural and indigenous groups. In the urban group, most participants have an undergraduate university education, while in the rural and indigenous ones, most participants have secondary education. This same situation is presented in the socioeconomic stratum report. In the urban and rural groups, most participants are originally from an urban environment. In all three groups, the majority of participants do activities where they are in contact with nature during their free time (see Table 1).

Table 1. Descriptive participants by group.

\begin{tabular}{|c|c|c|c|c|c|c|}
\hline \multirow{2}{*}{$\begin{array}{c}\text { Variables } \\
\text { Sex }\end{array}$} & \multicolumn{2}{|c|}{ Urban $(n=66)$} & \multicolumn{2}{|c|}{ Rural (n = 212) } & \multicolumn{2}{|c|}{ Indigenous $(n=110)$} \\
\hline & f & $\%$ & $\mathrm{f}$ & $\%$ & f & $\%$ \\
\hline Male & 34 & 51.5 & 98 & 46.2 & 33 & 30.0 \\
\hline Female & 32 & 48.5 & 114 & 53.8 & 77 & 70.0 \\
\hline Education & $\mathbf{f}$ & $\%$ & $\mathbf{f}$ & $\%$ & $\mathbf{f}$ & $\%$ \\
\hline Primary & - & - & 6 & 2.8 & 5 & 4.5 \\
\hline Secondary & 11 & 16.7 & 188 & 88.7 & 90 & 81.8 \\
\hline Technical & 9 & 13.6 & 5 & 2.4 & 13 & 11.8 \\
\hline Technological & 4 & 6.1 & 6 & 2.8 & - & - \\
\hline Undergraduate & 34 & 51.5 & 4 & 1.9 & 2 & 1.8 \\
\hline Postgraduate & 8 & 12.1 & 3 & 1.4 & - & - \\
\hline Stratum & f & $\%$ & f & $\%$ & $\mathbf{f}$ & $\%$ \\
\hline 1 & 15 & 22.7 & 138 & 65.1 & 96 & 87.3 \\
\hline 2 & 41 & 62.1 & 68 & 32.1 & 12 & 10.9 \\
\hline 3 & 10 & 15.1 & 6 & 2.8 & 2 & 1.8 \\
\hline
\end{tabular}


Table 1. Cont.

\begin{tabular}{|c|c|c|c|c|c|c|}
\hline \multirow{2}{*}{$\begin{array}{c}\text { Variables } \\
\text { Sex }\end{array}$} & \multicolumn{2}{|c|}{ Urban $(n=66)$} & \multicolumn{2}{|c|}{ Rural $(n=212)$} & \multicolumn{2}{|c|}{ Indigenous $(n=110)$} \\
\hline & $\mathbf{f}$ & $\%$ & f & $\%$ & f & $\%$ \\
\hline Sector & $f$ & $\%$ & $\mathrm{f}$ & $\%$ & $\mathrm{f}$ & $\%$ \\
\hline Urban & 49 & 74.2 & 112 & 52.8 & 3 & 2.7 \\
\hline Rural & 17 & 25.8 & 100 & 47.2 & 107 & 97.3 \\
\hline $\begin{array}{l}\text { Do you do activities where yo } \\
\text { are in contact with nature } \\
\text { during your free time? }\end{array}$ & $\mathbf{f}$ & $\%$ & $\mathbf{f}$ & $\%$ & f & $\%$ \\
\hline Yes & 58 & 87.9 & 185 & 87.3 & 95 & 86.4 \\
\hline No & 8 & 12.1 & 27 & 12.7 & 15 & 13.6 \\
\hline
\end{tabular}

\subsection{Scales and Instruments}

"Climate change risk perception" scale: Made up of 16 items adapted from the risk perception scale $[67,68]$, including the traditional component factors of risk perception [69], fear, ignorance, and risk. A Likert scale was used, ranging from "totally disagree" (1) to "totally agree" (5).

"Beliefs about the causes of climate change" scale: These were questioned using two items that asked about the natural or anthropic origin (human action) of climate change. For each item or cause, a Likert scale was used, ranging from "totally disagree" (1) to "totally agree" (5).

"Environmental beliefs" scale: Made up of 15 items from the adaptation made by Amérigo and collaborators [22] of Thompson and Barton's [28] environmental beliefs scale. This adaptation is made up of three dimensions, namely Anthropocentrism, Egobiocentrism, and Biosphereism. Each dimension has 5 items. A Likert scale was used, ranging from "totally disagree" (1) to "totally agree" (5).

"Sustainable behavior" scale: Evaluates pro-ecological, altruistic, frugal, and equitable behavior, according to the version of Tapia-Fonllem and collaborators [41]. Pro-ecological behavior was measured using 13 items, according to Kaiser's adaptation [70]. A scale ranging from "never" (1) to "always" (5) was used. Regarding altruistic behavior, 9 items from Corral-Verdugo and collaborators' scale [71] were used. A scale ranging from "never" (1) to "always" (5) was used. Frugal behavior was evaluated using 6 items from CorralVerdugo and collaborators' scale [71]. A scale ranging from "never" (1) to "always" (5) was used. To measure equitable behavior, we included 7 items from Corral-Verdugo and collaborators' scale [71]. A scale ranging from 'totally disagree" (1) to "totally agree" (5) was used.

\subsection{Procedure}

The instruments were administered (in pencil and paper format) to the participants who voluntarily agreed to take part in the study, after understanding the research objectives and signing the informed consent. None of the volunteer participants refused to participate. They did not receive any money, and individual results were shown to whoever requested them.

\subsection{Data Analysis}

A descriptive analysis was carried out. Then, data normality was determined by conducting Kolmogorov Smirnov's analysis, and correlational and linear regressions were applied. An internal consistency analysis of the dimensions of the applied tests was also performed. To comply with the calculation of the indicated statistics, the SPSS software was used $\left(\mathrm{V} .23^{\circledR}\right)$. 


\section{Results}

Table 2 shows the descriptive statistics and the internal consistency of the scales used, expressed through Cronbach's alpha coefficient, which for most participants was acceptable (0.70). The biosphereism dimension of the "Environmental belief" scale (0.52) was the lowest; thus, it was not included in the correlational analyses. Beliefs about the causes of climate change as a consequence of human activities (anthropic) are higher than those considering the phenomenon as a consequence of purely natural causes. There is evidence of a higher level of agreement on "Equity" (general mean $=4.23$, in a range from 0 to 5). Scores of moderate levels of response were obtained for the "Risk perception of climate change" (general mean $=3.55$, in a range from 0 to 5 ) as well as for "Frugality" (general mean $=3.31$, in a range from 0 to 5 ) and "Pro-ecological behavior" (general mean $=3.23$, in a range from 0 to 5); the lowest score was obtained for "Altruism" (general mean $=2.97$, in a range from 0 to 5 ).

Table 2. Scale.

\begin{tabular}{rccc}
\hline & $\boldsymbol{M}$ & $\mathrm{SD}$ & $\boldsymbol{\alpha}$ \\
\hline Belief in the natural cause of climate change & 2.40 & 1.45 & - \\
Belief in the anthropic cause of climate change & 4.18 & 1.12 & 0.68 \\
Risk perception of climate change & 3.55 & 0.52 & 0.71 \\
Environmental beliefs_anthropocentrism dimension & 2.93 & 0.28 & 0.64 \\
Environmental beliefs-egobiocentrism dimension & 4.15 & 0.18 & 0.52 \\
Environmental beliefs-biosphereism dimension & 3.84 & 0.37 & 0.88 \\
Sustainable behavior & 3.48 & 0.56 & 0.80 \\
Pro-ecological behavior & 3.23 & 0.68 & 0.76 \\
Altruism & 2.97 & 0.66 & 0.69 \\
Frugality & 3.31 & 0.86 & 0.78 \\
\hline
\end{tabular}

A comparison of means among the three groups, identified according to their living context (rural, urban, and rural/indigenous), was carried out (see Table 3). Beliefs about anthropic causes of climate change are higher and more significant in the three groups than beliefs about natural causes, which is the highest for the urban participants. Both "Risk perception of climate change" and anthropocentric beliefs (Anthropocentrism) $(p<0.001)$ are significantly higher in the indigenous group, that is, they see human beings as exerting dominance over nature with no dependence on it and with the ability to transform it at their discretion. In contrast, the urban group shows higher and more significant scores in egobiocentric beliefs (Egobiocentrism) $(p<0.05)$, which means that this group has a positive view of the effects of nature on human beings and sees nature from a viewpoint of its intrinsic value and its benefits, which facilitate the connection between living beings, unlike the rural/ indigenous group (which has lower scores in Egobiocentrism than the rural group). The urban group also shows the highest scores in "Sustainable behavior", "Pro-ecological behavior", "Altruism", "Frugality", and "Equity", being significant values $(p<0.001)$ for the first and fourth variable. However, the indigenous group shows higher "Pro-ecological behavior" scores than the rural group.

To prove the normality assumptions of the sample, an analysis was carried out with the Kolmogorov-Smirnov test, which determined that none of the data behaved in a parametric way. A difference of medians was then run with the Kruskal-Wallis test. In line with this test, there are statistically significant differences between "Risk perception of climate change", "Environmental beliefs" (Anthropocentrism, Egobiocentrism), "Sustainable behavior", "Pro-ecological", and "Frugality". Subsequently, a correlational analysis was planned, which shows significant associations between the variables (Table 4). 
Table 3. Difference of means between the groups.

\begin{tabular}{|c|c|c|c|c|c|c|c|c|}
\hline \multirow{2}{*}{ Variables (Groups) } & \multicolumn{2}{|c|}{$\begin{array}{l}\text { Urban } \\
(n=66)\end{array}$} & \multicolumn{2}{|c|}{$\begin{array}{c}\text { Rural } \\
(n=212)\end{array}$} & \multicolumn{2}{|c|}{$\begin{array}{l}\text { Indigenous } \\
\quad(n=110)\end{array}$} & \multirow{2}{*}{$\begin{array}{c}\text { H de } \\
\text { Kruskal } \\
\text { Wallis }\end{array}$} & \multirow{2}{*}{ Sig. } \\
\hline & $X$ & DE. & $X$ & DE. & $X$ & DE. & & \\
\hline Belief in natural cause of climate change & 2.77 & 0.65 & 2.87 & 0.60 & 3.17 & 0.67 & 0.28 & 0.59 \\
\hline $\begin{array}{l}\text { Belief in anthropic cause of } \\
\text { climate change }\end{array}$ & 3.83 & 0.39 & 3.66 & 0.46 & 3.44 & 0.41 & 9.55 & $* 0.00$ \\
\hline Risk perception of climate change & 3.46 & 0.51 & 3.57 & 0.51 & 3.58 & 0.58 & 3.75 & $* 0.05$ \\
\hline $\begin{array}{c}\text { Environmental } \\
\text { beliefs-anthropocentrism }\end{array}$ & 2.41 & 0.80 & 2.83 & 0.95 & 3.47 & 0.91 & 12.40 & $* 0.00$ \\
\hline Environmental beliefs-egobiocentrism & 4.31 & 0.72 & 4.12 & 0.68 & 4.11 & 0.70 & 5.24 & $* 0.02$ \\
\hline Sustainable behavior & 3.84 & 0.40 & 3.44 & 0.53 & 3.35 & 0.63 & 30.29 & $* 0.00$ \\
\hline Pro-ecological behaviors & 3.76 & 0.54 & 3.11 & 0.64 & 3.16 & 0.71 & 46.46 & $* 0.00$ \\
\hline Altruism & 3.04 & 0.55 & 2.98 & 0.62 & 2.91 & 0.80 & 0.77 & 0.38 \\
\hline Frugality & 3.84 & 0.59 & 3.24 & 0.85 & 3.15 & 0.91 & 27.65 & $* 0.00$ \\
\hline Equity & 4.47 & 0.42 & 4.30 & 0.68 & 3.98 & 0.81 & 1.51 & 0.22 \\
\hline
\end{tabular}

Table 4. Correlational matrix.

\begin{tabular}{|c|c|c|c|c|c|}
\hline A & B & $\mathrm{C}$ & D & E & $\mathbf{F}$ \\
\hline A. Sustainable behavior & $-0.105 *$ & $0.131^{* *}$ & 0.321 ** & $0.333^{* *}$ & \\
\hline B. Belief in natural causes of climate change & & $-0.234 * *$ & & $-0.108 *$ & $0.257 * *$ \\
\hline C. Belief in anthropic causes of climate change & & & $0.205^{* *}$ & $0.202 * *$ & $-0.101 *$ \\
\hline D. Risk perception of climate change & & & & $0.430 * *$ & $0.378 * *$ \\
\hline E. Environmental beliefs-Egobiocentrism & & & & & $0.160 * *$ \\
\hline F. Environmental beliefs-Anthropocentrism & & & & & \\
\hline
\end{tabular}

*. Correlation is significant at 0.05 (bilateral). ${ }^{* *}$. Correlation is significant at 0.01 (bilateral).

Predictive analyses carried out through linear regression show that environmental beliefs in "Egobiocentrism" and "Risk perception of climate change" predict both "Sustainable" and "Pro-ecological Behavior", as well as the "Altruism", "Frugality", and "Equity" variables. The environmental belief that climate change causes are mainly natural in origin also contributes (negatively) to the variance of the presence of the "Equity" variable (Table 5).

Table 5. Predictive analysis (linear regression).

\begin{tabular}{|c|c|c|c|c|}
\hline \multirow{2}{*}{$\begin{array}{l}\text { Dependent and Independent Variables } \\
\text { by Regression }\end{array}$} & \multicolumn{2}{|c|}{ Standardized Coefficients } & \multirow{2}{*}{$\mathbf{R}^{2}$} & \multirow{2}{*}{$p$-Value } \\
\hline & Beta & Valor $p$ & & \\
\hline Sustainable behavior & & & 0.16 & 0.00 \\
\hline Risk perception of climate change & 0.22 & 0.00 & & \\
\hline Environmental beliefs-Egobiocentrism & 0.22 & 0.00 & & \\
\hline Pro-ecological behavior & & & 0.09 & 0.00 \\
\hline Risk perception of climate change & 0.17 & 0.00 & & \\
\hline Environmental beliefs-Egobiocentrism & 0.18 & 0.00 & & \\
\hline Altruism & & & 0.04 & 0.01 \\
\hline Risk perception of climate change & 0.11 & 0.06 & & \\
\hline Environmental beliefs-Egobiocentrism & 0.12 & 0.04 & & \\
\hline Frugality & & & 0.12 & 0.00 \\
\hline Risk perception of climate change & 0.19 & 0.00 & & \\
\hline Environmental beliefs-Egobiocentrism & 0.13 & 0.02 & & \\
\hline Equity & & & 0.20 & 0.00 \\
\hline Mainly natural & -0.13 & 0.01 & & \\
\hline Risk perception of climate change & 0.21 & 0.00 & & \\
\hline Environmental beliefs-Egobiocentrism & 0.27 & 0.00 & & \\
\hline
\end{tabular}




\section{Discussion}

This research aimed to determine the relationship between environmental beliefs and sustainable behavior in a group of inhabitants of southern Colombia and to prove a causal relation between environmental beliefs and beliefs about climate change, in relation to sustainable behavior.

The findings regarding the predominance of beliefs on the causes of climate change resulting from human (anthropic) activities, rather than the causes attributing the phenomenon to completely natural causes, show a global understanding about how most environmental deterioration is due to the fact that human activities affect individuals, groups, and organizations throughout the world, showing an important level of identification with the environment and its connection with the physical factors of the ecological context where they interact $[3,58]$. This contrasts with what Ameztegui and collaborators [72] found in a group of people from the Canadian forest sector, who mostly believe in the anthropic causes of climate change, considering this phenomenon as a threat to their well-being. It is, in contrast, in tune with what Austin and collaborators [10] concluded in relation to the concerns about climate change of Australian rural residents, finding that the environmental, financial, health, and social impacts of this phenomenon cause great concern. However, the results of this research suggest that this anthropic causal attribution is higher in the group of urban inhabitants than in the rural and indigenous ones. This suggests a potential line of actions worthy of being addressed in detail since, as proposed by Huddart-Kennedy and collaborators [11], there is a series of geographical influences between the urban and rural sectors that impact how their inhabitants behave and care about the environment. The origin of these influences may be linked to the specificities of the current circumstances of a given population or to the child socialization processes in these places. A case in point can be found in the research by Rülke and collaborators [4], conducted with rural inhabitants in Kenya. The study showed that most of the participants adopted an anthropocentric position on understanding the relations between human beings and the environment, specifically on the protection of diversity, which was explained by their opposition to protecting flora and fauna and the non-acceptance of their responsibility in caring for the forest, as well as the non-importance given to indigenous knowledge and the wisdom of nature. In contrast, Peterson St-Laurent and collaborators [73] found an anthropic causal attribution of climate change in inhabitants (50\% of the participants) from the main metropolitan areas in Vancouver and Victoria (Canada). These results highlight the importance of integrating the urban or rural origin of the participants into the analyses since the context influences how the environment, environmental problems, and adaptation strategies are conceived.

The high scores for the "Equity" variable highlight the tendency of the sample to recognize this value in their daily lives as a predisposing factor to greater sensitivity to the distribution of resources and exploitation of nature $[41,42,58,59]$. It stands in contrast to what was found by Tapia-Fonllem and collaborators [41] in their research on university students, and Corral-Verdugo and collaborators [58] on the general population, which may suggest that this factor goes beyond population differences.

Unlike what is reported by these authors, "Frugality" and "Pro-ecological behavior" only obtained moderate level scores in this study, a finding similar to that of Kaida and Kaida [74] on inhabitants from Stockholm (Sweden), and Corral-Verdugo and collaborators [58] on the Mexican population. It is striking that in the study by Tapia-Fonllem and collaborators [41], "Altruism" is one of the factors with the highest score, whereas, in our study, it obtained the lowest score. This is close to the findings of Corral-Verdugo and collaborators [58], where this variable obtained one of the lowest scores in the Mexican group. These changes could be due to both cultural differences and educational processes [51] of the groups under study. This suggests that the public policy sector needs to devise plans, programs, and actions aimed at strengthening these factors in order to achieve a greater commitment to caring for the environment, reducing global warming, coping 
with climate change effects, and mitigating its consequences for human populations and ecosystems [41].

There were positive and statistically significant correlations of high magnitude between the "Risk perception of climate change" and the dimensions of egobiocentrism and anthropocentrism, which corresponds to what was expected. However, significant negative correlations were also identified between the dimensions "Beliefs in natural causes of climate change" with "Sustainable behavior" and "Egobiocentrism", as well as higher climate change risk perception and anthropocentrism. These observations are coherent with the previous empirical references and show the need to strengthen the population's awareness of the consequences of climate change [2], the empowerment in the display of effective sustainable behavior in the short term [58,61], and the potential feeling of well-being generated from contact with nature [20].

Egobiocentrism and climate change perceptions are considered to be the main predictors of sustainable behavior characteristics. Certain traits, such as the feeling of well-being, relaxation, and increased happiness when in contact with nature, as well as the feeling of discomfort when perceiving the destruction of the environment [22], interact with the risk perception of climate change represented by the perception of human impact-especially that of future generations-as well as immediate action when facing already-identified threats. Together, these factors are the best predictors of actions related to responsible and regulated consumption [50] or protection of native fauna and flora [41]. This evidence is important when it comes to guaranteeing actions that lead both to the satisfaction of the common needs of the human species [51] and to the protection of the resource-providing ecosystems that fulfill these needs $[29,30]$. This way of thinking may be "desirable", in the sense that it attributes more responsibility for changes to individual behavior than to external bodies such as the government, scientists, or those who manage the means of production $[75,76]$. Yet, the human species' resilience and potential to adapt to new changes or even return to the historically defining conditions of such ecosystems should be acknowledged [77].

This work has the following limitations. The sampling was formed by convenience; this enabled us to ensure that a large number of participants were recruited. For future occasions, a stratified sampling could be used, as it allows greater representativeness of the subgroups assessed. In addition, it is possible that for some people, completing a booklet made up of eight scales could generate some fatigue that, in turn, could have biased the recorded information. Finally, the application form (pencil and paper) was, at some points, time-consuming for people with reading and writing difficulties, though this was solved with the timely assistance of the applicators.

Regarding new research prospects in this field, conducting studies with controlled observation of the variables is suggested to confirm the causal hypotheses that may emerge from this correlational study, as well as carrying out longitudinal studies mainly designed to evaluate the long-term impact of educational programs to promote frugal, proenvironmental, altruistic, and equitable actions for the benefit of the ecosystem.

In conclusion, then, the presence of positive personal traits, in conjunction with information regarding awareness of environmental deterioration, climate change, and the consequences for future life in order to demystify sets of beliefs about climate change, can predict the adoption of individual and collective actions for growth and sustainable development. However, it is necessary to conduct new studies that overcome the acknowledged limitations and that allow both a better explanation of the phenomena underlying sustainable behavior and the development of programs that impact people's daily lifestyles and reduce the risks for ecosystems in the near future.

Author Contributions: Conceptualization, D.K.A.N., E.D.T.S. and C.M.N.G.; Formal analysis, O.N.; Investigation, W.S.-B. and O.N.; Methodology, O.N.; Supervision, W.S.-B.; Writing-Original draft, W.S.-B.; Writing-Review \& Editing, O.N. All authors have read and agreed to the published version of the manuscript. 
Funding: This research received no external funding.

Institutional Review Board Statement: Not applicable.

Informed Consent Statement: Informed consent was obtained from all subjects involved in the study.

Data Availability Statement: Data presented in this manuscript are available upon request from the corresponding author.

Conflicts of Interest: The authors declare no conflict of interest.

\section{References}

1. García, F.I.V.; Durón, M.F.R.; Corral, V.V. Conectividad con la naturaleza y conducta sustentable: Una vía hacia las conductas pro-sociales y proambientales. Psicumex 2016, 6, 81-96. [CrossRef]

2. Gutiérrez-Pérez, J.; Perales-Palacios, F.J. Ambientalización curricular y sostenibilidad. Nuevos retos de profesionalización docente. Profr. Rev. Curríc. Form. Profr. 2012, 16, 5-14.

3. Torres-Hernández, T.; Barreto, I.; Vásquez, J.C.R. Creencias y normas subjetivas como predictores de intención de comportamiento proambiental. Suma Psicol. 2015, 22, 86-92. [CrossRef]

4. Rülke, J.; Rieckmann, M.; Nzau, J.M.; Teucher, M. How ecocentrism and anthropocentrism influence human-environment relationships in a kenyan biodiversity hotspot. Sustainability 2020, 12, 8213. [CrossRef]

5. Masson-Delmotte, V.; Zhai, P.; Pörtner, H.-O.; Roberts, D.; Skea, J.; Shukla, P.R.; Pirani, A.; Moufouma-Okia, W.; Péan, C.; Pidcock, R.; et al. Calentamiento Global de $1.5^{\circ} \mathrm{C}$. En Informe Especial del IPCC Sobre los Impactos del Calentamiento Global de $1.5^{\circ} \mathrm{C}$ con Respecto a los Niveles Preindustriales y las Trayectorias Correspondientes que Deberían Seguir las Emisiones Mundiales de Gases de Efecto Invernadero, en el Contexto del Reforzamiento de la Respuesta Mundial a la Amenaza del Cambio Climático, el Desarrollo Sostenible y los Esfuerzos por Erradicar la Pobreza; IPCC: Geneva, Switzerland, 2019; pp. 373-401.

6. Spence, A.; Poortinga, W.; Pidgeon, N.; Lorenzoni, I. Public perceptions of energy choices: The influence of beliefs about climate change and the environment. Energy Environ. 2010, 21, 385-407. [CrossRef]

7. Ricart, S.; Olcina, J.; Rico, A.M. Evaluating public attitudes and farmers' beliefs towards climate change adaptation: Awareness, perception, and populism at European level. Land 2019, 8, 4. [CrossRef]

8. Brownlee, M.T.; Powell, R.B.; Hallo, J.C. A review of the foundational processes that influence beliefs in climate change: Opportunities for environmental education research. Environ. Educ. Res. 2013, 19, 1-20. [CrossRef]

9. Skarstein, F. Climate beliefs in an oil-dependent economy: Norwegian pre-service science teachers' attitudes towards climate change. Environ. Educ. Res. 2020, 26, 491-510. [CrossRef]

10. Austin, E.K.; Rich, J.L.; Kiem, A.S.; Handley, T.; Perkins, D.; Kelly, B.J. Concerns about climate change among rural residents in Australia. J. Rural Stud. 2020, 75, 98-109. [CrossRef]

11. Huddart-Kennedy, E.; Beckley, T.M.; McFarlane, B.L.; Nadeau, S. Rural-Urban differences in environmental concern in Canada. Rural Sociol. 2009, 74, 309-329. [CrossRef]

12. Clerici, N.; Armenteras, D.; Kareiva, P.; Botero, R.; Ramírez-Delgado, J.P.; Forero-Medina, G.; Ochoa, J.; Pedraza, C.; Schneider, L.; Lora, C.; et al. Deforestation in Colombian protected areas increased during post-conflict periods. Sci. Rep. 2020, $10,4971$. [CrossRef]

13. Żelazna, A.; Bojar, M.; Bojar, E. Corporate social responsibility towards the environment in the Lublin region, Poland: A comparative study of 2009 and 2019. Sustainability 2020, 12, 4463. [CrossRef]

14. Esteban-Salvador, L.; Gargallo-Castel, A.F.; Pérez-Sanz, J. Environmental practices in firms located in underpopulated rural areas in Spain: The case of the province of Teruel. Int. J. Environ. Res. Public Health 2020, 17, 8993. [CrossRef] [PubMed]

15. Barclay, P.; Barker, J.L. Greener than thou: People who protect the environment are more cooperative, compete to be environmental, and benefit from reputation. J. Environ. Psychol. 2020, 72, 101441. [CrossRef]

16. Jenkins-Smith, H.C.; Ripberger, J.T.; Silva, C.L.; Carlson, D.E.; Gupta, K.; Carlson, N.; Ter-Mkrtchyan, A.; Dunlap, R.E. Partisan asymmetry in temporal stability of climate change beliefs. Nat. Clim. Chang. 2020, 10, 322-328. [CrossRef]

17. Altschuler, B.; Brownlee, M. Perceptions of climate change on the Island of Providencia. Local Environ. 2016, 21, 615-635. [CrossRef]

18. Bickerstaff, K. Risk perception research: Socio-Cultural perspectives on the public experience of air pollution. Environ. Int. 2004, 30, 827-840. [CrossRef]

19. Bickerstaff, K.; Walker, G. Clearing the smog? Public responses to air-quality information. Local Environ. 1999, 4, 279-294. [CrossRef]

20. Niemeyer, S.; Petts, J.; Hobson, K. Rapid climate change and society: Assessing responses and thresholds. Risk Anal. Int. J. 2005, 25, 1443-1456. [CrossRef]

21. Wakefield, S.E.; Elliott, S.J.; Cole, D.C.; Eyles, J.D. Environmental risk and (re) action: Air quality, health, and civic involvement in an urban industrial neighbourhood. Health Place 2001, 7, 163-177. [CrossRef]

22. Amérigo, M.; Aragonés, J.I.; de Frutos, B.; Sevillano, V.; Cortés, B. Underlying dimensions of ecocentric and anthropocentric environmental beliefs. Span. J. Psychol. 2007, 10, 97-103. [CrossRef] [PubMed]

23. Schwartz, S.H. Are there universal aspects in the structure and contents of human values? J. Soc. Issues 1994, 50, 19-45. [CrossRef] 
24. Schwartz, S.H.; Bilsky, W. Toward a theory of the universal content and structure of values: Extensions and cross-cultural replications. J. Personal. Soc. Psychol. 1990, 58, 878. [CrossRef]

25. Schultz, P.W.; Zelezny, L.C. Values and proenvironmental behavior: A five-country survey. J. Cross Cult. Psychol. 1998, 29, 540-558. [CrossRef]

26. Stern, P.C.; Dietz, T. The value basis of environmental concern. J. Soc. Issues 1994, 50, 65-84. [CrossRef]

27. Stern, P.C.; Dietz, T.; Kalof, L. Value orientations, gender, and environmental concern. Environ. Behav. 1993, 25, 322-348. [CrossRef]

28. Thompson, S.C.G.; Barton, M. Ecocentric and anthropocentric attitudes toward the environment. J. Environ. Psychol. 1994, 14, 149-157. [CrossRef]

29. Milenović, M.; Živković, S.; Veljković, M. The psychological perspective of climate changes. Teme Časopis Druš. Nauk. 2019, 43, 755-767.

30. Sierra-Barón, W. Retos medioambientales desde el sur colombiano: Implicaciones para el departamento del Huila. Bol. Colpsic 2018, 38, 9-11.

31. Sierra-Barón, W.; Medina-Arboleda, I.F.; Aguilera, H.E. Ambientalización del currículo en Educación Superior y consumo de agua en los hogares de estudiantes universitarios. Gest. Ambient. 2018, 21, 263-275. [CrossRef]

32. Saza Quintero, A.; Sierra-Barón, W.; Gómez-Acosta, C.A. Comportamiento proambiental y conocimiento ambiental en universitarios: El área de conocimiento hace la diferencia? CES Psicol. 2021, 14. Available online: https://revistas.ces.edu.co/index.php/ psicologia/article/view/5674 (accessed on 22 February 2021).

33. Suárez, M.A.C.; Cunalata, C.P.M.; Robalino, O.E.R.; Pérez, J.G.V.; Cárdenas, J.C.S.; Almeida, E.L.S. Estimación cuantitativa y cálculo de emisiones ambientales (huella de carbono), en el terminal terrestre de la ciudad de Guaranda. Cienc. Digit. 2018, 2, 283-293.

34. Useros, J.L.F. El cambio climático: Sus causas y efectos medioambientales. An. Real Acad. Med. Cir. Valladolid 2013, 50, 71-98.

35. Velázquez de Castro, G.F. Cambio climático y protocolo de Kioto. Ciencia y estrategias: Compromisos para España. Rev. Esp. Salud Pública 2005, 79, 191-201. [CrossRef]

36. Yuriev, A.; Sierra-Barón, W. Exploring sustainability cross-culturally: Employees' beliefs on green behaviors. Sustain. Dev. 2020, 28, 1-9. [CrossRef]

37. Xu, F.; Huang, L.; Whitmarsh, L. Home and away: Cross-Contextual consistency in tourists' pro-environmental behavior. J. Sustain. Tour. 2020, 28, 1-17. [CrossRef]

38. Corral-Verdugo, V.; Lucas, M.Y.; Tapia-Fonllem, C.; Ortiz-Valdez, A. Situational factors driving climate change mitigation behaviors: The key role of pro-environmental family. Environ. Dev. Sustain. 2019, 22, 1-17. [CrossRef]

39. Rascón, C.M.; Corral, V.V. Consecuencias positivas intrínsecas de la conducta sustentable: Una investigación con estudiantes universitarios. PSICUMEX 2013, 3, 62-75.

40. Navarro, O.; Tapia-Fonllem, C.; Fraijo-Sing, B.; Roussiau, N.; Ortiz-Valdez, A.; Guillard, M.; Wittenberg, I.; Fleury-Bahi, G. Connectedness to nature and its relationship with spirituality, wellbeing and sustainable behaviour. Psyecology 2020, 11, 37-48. [CrossRef]

41. Tapia-Fonllem, C.; Corral-Verdugo, V.; Fraijo-Sing, B.; Durón-Ramos, F. Assessing sustainable behavior and its correlates: A measure of pro-ecological, frugal, altruistic and equitable actions. Sustainability 2013, 5, 711-723. [CrossRef]

42. Corral, V. Psicología de la Sustentabilidad. Un Análisis de lo Que Nos Hace Pro-Ecológicos y Pro-Sociales; Editorial Trillas: Mexico City, Mexico, 2010.

43. Barrera-Hernández, L.F.; Corral-Verdugo, V.; Fraijo-Sing, B.S.; Tapia-Fonllem, C.O. Psychological and physical indicators of a transcendental positive environment and its impact on sustainable behavior. J. Psychol. Educ. Res. 2018, 26, 51-68.

44. Corral-Verdugo, V.; Frías-Armenta, M.; García-Cadena, C. Introduction to the psychological dimensions of sustainability. In Psychological Approaches to Sustainability; Victor, C.V., Martha, F.A., Cirilo, G.C., Eds.; Nova Science Publishers: New York, NY, USA, 2013; pp. 3-18.

45. De Young, R. Some psychological aspects of reduced consumption behavior: The role of intrinsic satisfaction and competition motivation. Environ. Behav. 1996, 28, 358-409. [CrossRef]

46. Iwata, O. Coping style and three psychological measures associated with environmentally responsible behavior. Soc. Behav. Personal. Int. J. 2002, 30, 661-669. [CrossRef]

47. Lastovicka, J.L.; Bettencourt, L.A.; Shaw Hughner, R.; Kuntze, R.J. Lifestyle of the tight and frugal: Theory and measurement. J. Consum. Res. 1999, 26, 85-98. [CrossRef]

48. Muiños, G.; Suárez, E.; Hess, S.; Hernández, B. Frugality and psychological wellbeing. The role of voluntary restriction and the resourceful use of resources. Psyecology 2015, 6, 169-190. [CrossRef]

49. Bhatti, Y.A. What is frugal, what is innovation? Towards a theory of frugal innovation. SSRN Electron. J. 2012, 1-45. [CrossRef]

50. Pires, P.P.; Bastos, A.C.M.F.; Meirelles, É.D.L.; Peixoto, J.M.; Candido, N.D.B.; Mose, L.D.B. Factorial structure of the frugality scale: Exploratory evidence. Psico USF 2019, 24, 1-9. [CrossRef]

51. Tapia-Fonllem, C.; Fraijo-Sing, B.; Corral-Verdugo, V.; Ortiz Valdez, A. Education for sustainable development in higher education institutions: Its influence on the pro-sustainability orientation of Mexican students. SAGE Open 2017, 7, 1-15. [CrossRef]

52. Gärling, T.; Fujii, S.; Gärling, A.; Jakobsson, C. Moderating effects of social value orientation on determinants of proenvironmental behavior intention. J. Environ. Psychol. 2003, 23, 1-9. [CrossRef] 
53. Joireman, J.A.; Lasane, T.P.; Bennett, J.; Richards, D.; Solaimani, S. Integrating social value orientation and the consideration of future consequences within the extended norm activation model of proenvironmental behaviour. Br. J. Soc. Psychol. 2001, 40, 133-155. [CrossRef]

54. Van Lange, P. Cooperation and competition. In Encyclopedia of Psychology 2; Kazdin, A., Ed.; APA: Washington, DC, USA; Oxford University Press: New York, NY, USA, 2000; pp. 296-300.

55. Hopper, J.R.; Nielsen, J.M. Recycling as altruistic behavior: Normative and behavioral strategies to expand participation in a community recycling program. Environ. Behav. 1991, 23, 195-220. [CrossRef]

56. García, M.I.; Estévez, H.I.; Letamendía, B.P. El CUIDA como instrumento para la valoración de la personalidad en la evaluación de adoptantes, cuidadores, tutores y mediadores. Psychosoc. Interv. 2007, 16, 393-407. [CrossRef]

57. Sober, E.; Wilson, D.S. Unto Others: The Evolution and Psychology of Unselfish Behavior; Harvard University Press: Cambridge, MA, USA, 1998.

58. Corral-Verdugo, V.; Tapia-Fonllem, C.; Ortiz-Valdez, A. On the relationship between character strengths and sustainable behavior. Environ. Behav. 2015, 47, 877-901. [CrossRef]

59. Veenhoven, R. Is life getting better? How long and happy people live in modern society. Eur. Psychol. 2006, 10, 330-343. [CrossRef]

60. Clayton, S.; Devine-Wright, P.; Stern, P.C.; Whitmarsh, L.; Carrico, A.; Steg, L.; Swim, J.; Bonnes, M. Psychological research and global climate change. Nat. Clim. Chang. 2015, 5, 640-646. [CrossRef]

61. Gifford, R. Environmental psychology matters. Annu. Rev. Psychol. 2014, 65, 541-579. [CrossRef] [PubMed]

62. Ato, M.; López-García, J.J.; Benavente, A. Un sistema de clasificación de los diseños de investigación en psicología. Ann. Psychol. 2013, 29, 1038-1059. [CrossRef]

63. Gratani, M.; Sutton, S.G.; Butler, J.R.A.; Bohensky, E.L.; Foale, S. Indigenous environmental values as human values. Cogent Soc. Sci. 2016, 2. [CrossRef]

64. Machi, M. 2008 Indigenous and Traditional Peoples and Climate Change Issues Paper. Available online: https://www2.ohchr. org/english/issues/climatechange/docs/IUCN.pdf (accessed on 22 February 2021).

65. Corporación Autonoma Regional del Alto Magdalena (CAM). Plan de acción institucional 2020-2023. Huila Territorio de Vida, Sostenibilidad y Desarrollo; Corporación Autónoma Regional del Alto Magdalena (CAM): Neiva, Colombia, 2020.

66. Programa de Naciones Unidas Para el Desarrollo. Caquetá, Retos y Desafios Para el Desarrollo Sostenible; United Nations Development Programme: New York, NY, USA, 2019.

67. Lemée, C.; Fleury-Bahi, G.; Navarro, O. Impact of place identity, self-efficacy and anxiety state on the relationship between coastal flooding risk perception and the willingness to cope. Front. Psychol. 2019, 10, 499. [CrossRef]

68. Navarro, O.; Chaves, L.; Sus, J.D.P.; Betancur, M.I.N. Risk perception and coping strategies in population exposed and not exposed to flooding risk. Interam. J. Psychol. 2016, 50, 331-346.

69. Slovic, P. Perception of risk. Science 1987, 236, 280-285. [CrossRef] [PubMed]

70. Kaiser, F.G. A general measure of ecological behavior. J. Appl. Soc. Psychol. 1998, 28, 395-422. [CrossRef]

71. Corral-Verdugo, V.; Tapia, C.; Fraijo, B.; Mireles, J.; Márquez, P. Determinantes psicológicos de los estilos de vida sustentables. Rev. Mex. Psicol. 2008, 25, 313-327.

72. Ameztegui, A.; Solarik, K.A.; Parkins, J.R.; Houle, D.; Messier, C.; Gravel, D. Perceptions of climate change across the Canadian forest sector: The key factors of institutional and geographical environment. PLoS ONE 2018, 13, e0197689. [CrossRef]

73. Peterson St-Laurent, G.; Hagerman, S.; Kozak, R.; Hoberg, G. Public perceptions about climate change mitigation in British Columbia's forest sector. PLoS ONE 2018, 13, e0195999. [CrossRef] [PubMed]

74. Kaida, N.; Kaida, K. Pro-Environmental behavior correlates with present and future subjective well-being. Environ. Dev. Sustain. 2015, 18, 111-127. [CrossRef]

75. Ellis, R.J.; Thompson, F. Culture and the environment in the Pacific Northwest. Am. Political Sci. Rev. 1997, 91, 885-897. [CrossRef]

76. Poortinga, W.; Steg, L.; Vlek, C. Myths of nature and environmental management strategies. A field study on energy reductions in traffic and transport. In People, Places and Sustainability; Moser, G., Pol, E., Bernard, Y., Bonnes, M., Corralizia, J.A., Giuliani, V., Eds.; Hogrefe \& Huber Publisher: Seattle, WA, USA, 2003; pp. 280-289.

77. Steg, L.; Sievers, I. Cultural theory and individual perceptions of environmental risks. Environ. Behav. 2000, 32, 250-269. [CrossRef] 